\section{Cocoa Shade and Manurial Experiment in Ghana}

Contrary to general experience with other world crops, cocoa grown in West Africa had never been shown to respond to fertilizer, for reasons discussed by T. N. Hoblyn ${ }^{1}$. The recent successful control of capsid pests and the availability of uniform cocoa, however, has now made accurate experimentation possible.

In October 1956, at this Institute an area containing ten-year-old Amelonado trees planted in straight lines at $8 \mathrm{ft} . \times 8 \mathrm{ft}$. under uniform Gliricidia maculata shade $(24 \mathrm{ft} . \times 24 \mathrm{ft}$.) was chosen for shade removal and fertilizer application. The trees were in their third year of bearing and pre-treatment records were available. Fifteen plots, each containing 300 trees, were marked out. The treatments applied were: original shade/no fertilizer; original shade/fertilizer mixture; no shade/no fertilizer ; no shade/fertilizer mixture. All treatments are replicated three times, each replicate having 300 trees, thus making a total of 3,600 experimental trees. The three extra plots form guard plots between shaded and unshaded cocoa.

The fertilizers were broadcast by hand, and the types, rates and times of application are shown in Table 1.

\begin{tabular}{|c|c|c|c|c|c|c|}
\hline \multirow{2}{*}{$\begin{array}{l}\text { Applica- } \\
\text { tion }\end{array}$} & \multirow{2}{*}{ Date } & \multirow{2}{*}{$\begin{array}{l}\text { Fertilizer used } \\
\text { in mixture }\end{array}$} & \multicolumn{4}{|c|}{ Rates (lb./acre) } \\
\hline & & & $\mathrm{N}$ & $\mathrm{P}_{2} \mathrm{O}_{5}$ & $\overline{\mathrm{K}_{\mathbf{2}} \mathrm{O}}$ & $\mathrm{MgO}$ \\
\hline 1 & Oct. 1956 & $\begin{array}{l}\text { Ammonium } \\
\text { phosphate }(11 \\
\text { per cent } \mathrm{N}_{46}, 46 \\
\left.\text { per cent } \mathrm{P}_{2} \mathrm{O}_{5}\right) \\
\text { Single suyer- } \\
\text { phosphate }(18 \\
\left.\text { per cent } \mathrm{P}_{2} \mathrm{O}_{5}\right) \\
\text { Sulphate of } \\
\text { potash }(48 \text { per } \\
\left.\text { cent } \mathrm{K}_{2} \mathrm{O}\right) \\
\text { Magnesium sul- } \\
\text { phate }(16 \cdot 2 \\
\text { per cent } \mathrm{MgO})\end{array}$ & 13 & 91 & 90 & 46 \\
\hline 2 & April 1957 & $\begin{array}{l}\text { Urea (46 per } \\
\text { cent N) } \\
\text { Triple super- } \\
\text { phosphate }(47 \\
\left.\text { per cent } \mathrm{P}_{2} \mathrm{O}_{5}\right)\end{array}$ & 50 & 30 & - & $\longrightarrow$ \\
\hline 3 & Sept. 1957 & Urea & 50 & 二 & 一 & - \\
\hline
\end{tabular}

The shade was removed from all the non-shaded plots by poisoning the shade trees with 'Phortox' in March-April 1957.

The yields, expressed in pounds dry cocoa per acre, after one year of treatment are given in Table 2.

Table 2. YIELDS EXPRESSED IN LB. DRY COOOA/ACRE

\begin{tabular}{|c|c|c|c|c|}
\hline \multirow[t]{2}{*}{ Treatments } & \multicolumn{3}{|c|}{$\begin{array}{c}\text { First fertilizer mixture applied } \\
\text { October 1956. Shade removed } \\
\text { March 1957. } \\
\text { Pretreatment yields }\end{array}$} & \multirow{2}{*}{$\begin{array}{l}\text { After } \\
\text { treat- } \\
\text { ment } \\
\text { yields } \\
1957-58\end{array}$} \\
\hline & $1954-55$ & $1955-56$ & $1956-57$ & \\
\hline $\begin{array}{l}\text { Original shade/no } \\
\text { fertilizer } \\
\text { Original shade/fertil. }\end{array}$ & 30 & 44 & 205 & 615 \\
\hline $\begin{array}{l}\text { izer mixture } \\
\text { No shade/no fertilizer }\end{array}$ & $\begin{array}{l}24 \\
19\end{array}$ & $\begin{array}{l}32 \\
29\end{array}$ & $\begin{array}{l}211 \\
170\end{array}$ & $\begin{array}{r}869 \\
1,079\end{array}$ \\
\hline $\begin{array}{l}\text { No shade/fertilizer } \\
\text { mixture }\end{array}$ & 20 & 18 & 173 & 1,574 \\
\hline
\end{tabular}

Shaded/fertilized, unshaded/fertilized and unshaded/unfertilized treatments all showed significant increases in yield compared with the shaded/unfertilized control when an analysis of covariance was carried out. It is realized that one year's results are not sufficient to provide any definite general con- clusions; but the sparsity of published information about the responses of cocoa to such treatments, especially in West Africa, has caused us to report these preliminary results. Fuller details of the investigations will be published elsewhere.

R. K. Cunningham

J. LAMB

West African Cocoa Research Institute, Tafo, Ghana.

${ }^{`}$ Hoblyn, T. N., World Crops, 8, No. 9 (Sept. 1956).

\section{Inheritance of Photoperiodic Reaction in Rice}

Aus (summer) and Aman (winter) are the two important types of rice cultivated in Bengal, northeast India. The majority of the varieties of summer rice are photo-indifferent (period bound), while all the winter varieties are short-day (season bound) plants ${ }^{1,2}$.

In practice, both summer and winter varieties are sown at the same time, at the beginning of the rice season in May-June, when the advent of rains ensures plenty of moisture required for good growth of the crop. The summer varieties, which are photoindifferent, flower about 90 days after sowing and are ready for harvest in another month, in September. The winter varieties, which are short-day plants, do not flower until the length of the day decreases to less than $11.5 \mathrm{hr}$, in October-November. These varieties are harvested in November-December. As a rule, however, the winter varieties are much heavier yielders and better in grain quality than the summer varieties. It is of interest, therefore, to elucidate the inheritance of photoperiodic reactions in summer and winter rice, with the view of combining the early harvesting of the summer varieties with the high yield and good grain qualities of the winter varieties.

Reciprocal crosses were therefore attempted during the season of 1956 with plants, grown in pots, of two summer varieties, namely Charnock and Dhairal, and two winter varieties, namely, Patnai-23 and Bhasamanik, there being in all eight different combinations of crossings.

The combinations employed, the number of crosses actually attempted, the numbers of seeds gathered and of seeds germinating in the following season, and the number of plants showing hybrid characters under the respective combinations are shown in Table 1.

For these crosses flowering coincidence was effected in two ways. First, flowering of the winter varieties was hastened by short-day treatment to coincide with flowering of the summer varieties in their normal season. Secondly, a series of sowings of the summer varieties was made at fortnightly intervals until the end of August, to obtain coincidence of their flowering

\begin{tabular}{|c|c|c|c|c|c|}
\hline क Parent & ¿ Parent & $\begin{array}{l}\text { No. of } \\
\text { flowers } \\
\text { eross- } \\
\text { pollin- } \\
\text { ated }\end{array}$ & $\begin{array}{c}\text { No. } \\
\text { of } \\
\text { seeds } \\
\text { pro- } \\
\text { duced }\end{array}$ & $\begin{array}{l}\text { No. of } \\
\text { seeds } \\
\text { germ- } \\
\text { inated }\end{array}$ & $\begin{array}{l}\text { No. of } \\
\text { plants } \\
\text { showing } \\
\text { hybrid } \\
\left(F_{1}\right) \\
\text { char- } \\
\text { acters }\end{array}$ \\
\hline $\begin{array}{l}\text { (1) Bhasamanik } \\
\text { (2) Dhairal } \\
\text { (3) Patnai-23 } \\
\text { (4) Dhairal } \\
\text { (5) Bhasamanik } \\
\text { (6) Charnock } \\
\text { (7) Patnai-23 } \\
\text { (8) Charnock }\end{array}$ & $\begin{array}{l}\times \text { Dhairal } \\
\times \text { Bhasamanik } \\
\times \text { Dhairal } \\
\times \text { Patnai-23 } \\
\times \text { Charnock } \\
\times \text { Bhasamanik } \\
\times \text { Charnock } \\
\times \text { Patnai-23 }\end{array}$ & $\begin{array}{l}44 \\
37 \\
18 \\
31 \\
33 \\
16 \\
29 \\
45\end{array}$ & $\begin{array}{r}15 \\
8 \\
9 \\
9 \\
8 \\
1 \\
8 \\
7\end{array}$ & $\begin{array}{r}14 \\
5 \\
9 \\
9 \\
4 \\
0 \\
7 \\
5\end{array}$ & $\begin{array}{l}1 \\
1 \\
2 \\
1 \\
1 \\
0 \\
0 \\
4\end{array}$ \\
\hline
\end{tabular}

